NOTED:

Documentary

exposes dark

side of Tongan

diaspora

Gangsters in Paradise - The Deportees of Tonga. Documentary. 2019. Director: Ursula Williams. Vice/Zealandia: www.youtube.com/ watch?v=72u5q-0R48A

T'S LIKE crabs being stuck in a bucket scratching each other to get out.'

'It's like rubbish dumping.'

Those are two views about the crisis facing Tonga as countries like the United States, Australia and New Zealand deport criminals to the kingdom.

The first comes from a deportee who talks about how it feels being sent back to struggle for a living in a country with which he and other former prisoners are often barely familiar.

The other is from Tonga's Commissioner of Prisons, who wants western countries to take more responsibility for the people they deport and stop treating Tonga - and Samoa and Fiji-as dumping grounds for people they regard as rubbish. They are, he reminds us, human beings.

The two views come from a hard hitting documentary, Gangsters in Paradise - The Deportees of Tonga.

Made as part of the Vice/Zealandia series of documentaries, Gangsters in Paradise is not comfortable viewing. It begins with an interview with a

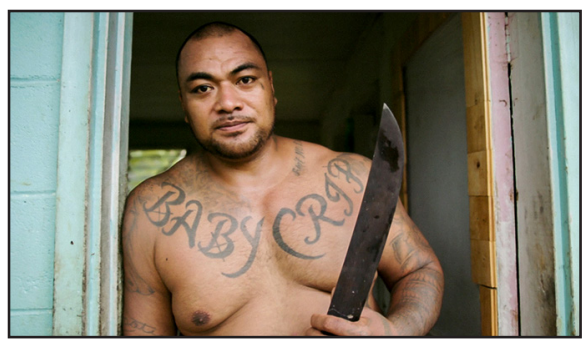

deportee who admits to having been jailed when he was barely out of childhood for shooting another boy four times in the stomach.

While some of the interviewees regard their time in prison as a chance to re-think their lives and gain a different perspective, others have brought nothing but trouble to Tonga. The kingdom is in the midst of a methamphetamine crisis and some deportees have gone back into the drugs trade.

As the film's associate producer, Todd Henry, recounts elsewhere in this edition, Gangsters in Paradise was the result of careful planning and lots of patience.

The half hour documentary has been watched by more than five million people since it was uploaded to YouTube and is a brilliant example of how short films can carry a big punch. It also shows how online platforms can reach out to global audiences, especially when they feature a diasporic community like Tonga's, which stretches from Sydney to Salt Lake City.

This is the dark side of Appudurai's ethnoscapes, a reminder that the movement of people can end in dislocation and, sometimes, death.-PHILIP CASS is reviews editor of Pacific Journalism Review. 


\section{A window into a displaced Pacific community}

Banabans of Rabi: A Story of Survival, a documentary by Blessen Tom and Hele Ikimotu. 10 minutes. Pacific Media Centre, Auckland University of Technology: www.youtube.com/ user/pacmedcentre

$\mathrm{O}$ NE thought in particular is likely to linger in the mind of anyone who watches Banabans of Rabi-how can people who have endured such hardship remain so happy?

Produced by Auckland University of Technology students Hele Ikimotu and Blessen Tom as part of the Pacific Media Centre's 2018 Bearing Witness climate project, the documentary provides a window into the houses of the smiling people whose ancestors were forcibly displaced from their home island of Banaba in the 1940s.

Now part of Kiribati, Banaba was, and still is, rich in phosphate, and the British Phosphate Commission confiscated it after World War II. Over 20 million tonnes were mined from the island, much of it used to fertilise land in New Zealand.

With Banaba rendered uninhabitable, the residents were relocated to Rabi Island in northern Fiji where many of their descendants remain to this day. The narrative captures the lives and histories of these people against the verdant backdrop of tropical Rabi.

While the film is immensely topical through its perspective of community displacement in the Pacific - something that climate change will only exacer-

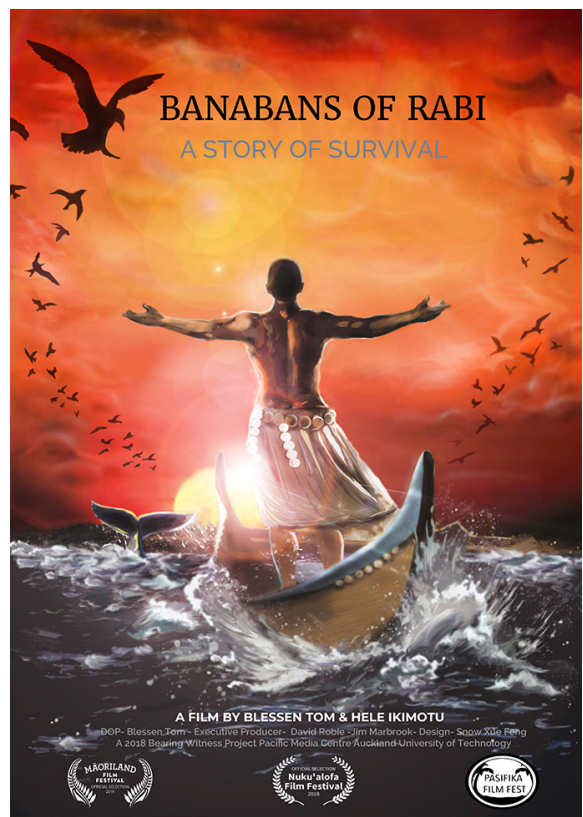

bate-it also weaves a deeply personal and intimate element through Ikimotu's Banaban heritage.

His mother was born on Rabi and the film features interviews with her and older relatives who live on the island today. They discuss the early days of integrating into a new home, harvesting copra and the way their village has been changed by rising tides.

'They definitely had their challenges,' narrates Ikimotu. 'And now the Rabi Islanders are faced with a new challenge - climate change.'

Blessen Tom's stunning shots capture the natural beauty of the island and its people while the spirited singing of the Rabi Islanders plays throughout.

All this effectively captures the essence of a versatile community abounding in wholesome happiness and not easily shaken.

As the narrator concludes: 
It warmed my heart to see that they were still happy, despite all the challenges that they have gone through and the new threat of climate change.

The Banabans are survivors.

The documentary premiered at the 2018 Nuku'alofa International Film Festival in Tonga and has also been screened at the Pasifika Film Festival in Salt Lake City, United States. The New Zealand premiere was held at Māoriland Film Festival 2019. It is due to be released on the Pacific Media Centre's YouTube channel later in 2019.-MICHAEL ANDREW is Pacific Media Watch contributing editor.

\section{Islanders call for climate change action in new student film}

Subject to Change. 2018. Documentary. Director: Wiktoria Ojrzyńska. Massey University/ MFAT: www. youtube.com/watch?v=VupDgO$4 \mathrm{kC} 8$

A S TOO many world leaders continue to do too little about climate change, powerful voices continue to call for action.

From Pope Francis to David Attenborough, there are global demands that something be done before it is too late. Now ordinary Pacific Islanders are having their say in a new short film, Subject to Change.

Using interviews with a range of people whose lives will be affected by climate change, the film explores their concerns, hopes and fears for the future.

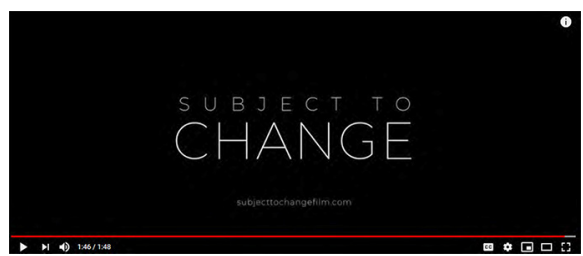

Changing weather patterns are already causing hardship, something underlined by the testimony of people who survived a cyclone in Fiji.

The film also warns that it is the younger generation - those who will be in their 30s in 2050 - who will have to contend with when the worst effects of sea level changes.

The film was premiered at the UN Climate Change Conference in Katowice, Poland, at the end of 2018 and has been released on YouTube.

The film was produced by Amiria Ranfurly, who is of Niuean-New Zealand descent, and Polish director Wiktoria Ojrzyńska. Both are students at Massey University.

The film was produced in collaboration with New Zealand's Ministry of Foreign affair and Trade. - PHILIP CASS is reviews editor of Pacific Journalism Review. 